\title{
Latent tuberculosis: the snake inside the egg
}

\author{
Fernando Bellissimo-Rodrigues ${ }^{[1]}$, Afonso Dinis Costa Passos ${ }^{[1]}$ \\ and Antônio Ruffino-Netto ${ }^{[1]}$
}

[1]. Departamento de Medicina Social, Faculdade de Medicina de Ribeirão Preto, Universidade de São Paulo, Ribeirão Preto, SP.

Despite the worldwide effort to control the spread of tuberculosis $(\mathrm{Tb})$, this disease continues to kill approximately 1.3 million people worldwide each year ${ }^{1}$. A comparison of this number with the number of people killed by recent natural catastrophes reveals that $\mathrm{Tb}$ kills the equivalent of 4.4 Haiti earthquakes or 7 Southeast Asia tsunamis, with one large difference: such catastrophes pass and take years or decades to repeat, but $\mathrm{Tb}$ takes its toll almost inexorably, year after year. Brazil is among the 22 countries considered to harbor approximately $80 \%$ of all $\mathrm{Tb}$ cases worldwide ${ }^{1-4}$.

These numbers convey a clear message to the healthcare and scientific communities, suggesting that the measures taken to control $\mathrm{Tb}$ are insufficient. Currently, most of the efforts to control $\mathrm{Tb}$ are directed at early diagnosis and adequate treatments for patients with active disease, approach including the Directly Observed Therapy Short-course (DOTS), with the expectation that these efforts will stop the transmission of $\mathrm{Tb}$ and eventually reduce the burden of this disease ${ }^{1,2,6,7}$.

Although extremely important, these strategies have two relevant limitations. First, because approximately one-third of the world's population is already infected with the Mycobacterium tuberculosis complex, these infected individuals are already at risk of developing $\mathrm{Tb}$ disease, regardless of their contact with an infective person ${ }^{1}$. Second, given the insidious nature of disease progression, most infected patients will not seek medical care until weeks, months or even years have elapsed since the beginning of the transmission period. Therefore, a single sputum smear-positive $\mathrm{Tb}$ patient is estimated to be able to disseminate the infection to $10-15$ close contacts each year ${ }^{5,6}$. Additionally, even when patients seek medical aid, the diagnosis may not be easily recognized by doctors due to the pleomorphic nature of this disease, resulting in the exposure of both healthcare workers and other patients under medical care to Tb infection ${ }^{3,8}$.

We believe that it is time to be proactive, exposing and treating latent $\mathrm{Tb}$ before it becomes active ${ }^{5,6,9}$. Among the 2 billion people estimated to harbor $\mathrm{Tb}$ worldwide, although most will never develop $\mathrm{Tb}$ disease, approximately $10 \%$ will develop

Address to: Dr. Fernando Bellissimo-Rodrigues. Depto $\mathrm{o}$ de Medicina Social/HC/ FMRP/USP. Av. Bandeirantes 3900/2 ${ }^{\circ}$ andar, Bairro Monte Alegre, 14049-900 Ribeirão Preto, SP, Brasil.

Phone: 55 16 3602-2714; Fax: 5516 3602-1562.

e-mail: fbellissimo@fmrp.usp.br

Received 27 August 2013

Accepted 21 November 2013
$\mathrm{Tb}$ disease at an unpredictable time in their lives. Although we do not know exactly who these 200 million people are, we have some important clues $^{2,5,6}$. We know that $M$. tuberculosis is an obligate intracellular parasite, which means that an adaptive cellular immune response is essential for the host to control the disease. Subsequently, all demographic and clinical conditions that suppress this arm of the immune reaction will enhance the risk of developing active $\mathrm{Tb}^{6}$.

Therefore, we can predict that a significant portion of the $10 \%$ will comprise children, malnourished individuals, human immunodeficiency virus (HIV)-infected patients, diabetics, patients with liver or kidney failure and users of anti-tumor necrosis factor alpha (TNF $\alpha$ ), systemic corticosteroids or other immunosuppressive drugs. Thus, an important strategy for $\mathrm{Tb}$ control in the general population will be the identification of latent $\mathrm{Tb}$ carriers among those personswhich can be accomplished by a tuberculin skin test, an interferon $\gamma($ IFN- $\gamma)$ release assay, a physical examination and a chest radiography, to exclude active disease and evaluate signs of previous pulmonary $\mathrm{Tb}^{10}$. The treatment of latent $\mathrm{Tb}$ with isoniazid, rifampin or both would subsequently reduce the risk of developing active $\mathrm{Tb}$ disease by at least $60 \%$ for these individuals, which will eventually reduce the risk of transmission in the community ${ }^{11}$.

It is noteworthy that many different medical specialties are involved in the follow-up of these patients, and thus, we must work in a coordinated manner to expose and reduce this huge one million people each year, despite the availability of a vaccine and inexpensive, effective treatments ${ }^{2,6}$.

\section{CONFLICT OF INTEREST}

The authors declare that there is no conflict of interest.

\section{REFERENCES}

1. World Health Organization. Globaltuberculosisreport2013.[Cited2013October23]. Available at: http://apps.who.int/iris/bitstream/10665/91355/1/9789241564656 eng.pdf/.

2. Ministério da Saúde do Brasil. Manual de Recomendações para o Controle da Tuberculose no Brasil 2011. [Cited 2013 August 20]. Available at: http://portal.saude.gov.br/portal/arquivos/pdf/manual_de_ recomendacoes_tb.pdf.

3. Ducati RG, Ruffino-Netto A, Basso LA, Santos DS. The resumption of consumption- A review on tuberculosis. Mem Inst Oswaldo Cruz 2006; 101: 697-714. 
4. Ruffino-Netto A. Tuberculose: a calamidade negligenciada. Rev Soc Bras Med Trop 2002; 35:51-58.

5. Centers for Disease Control and Prevention (CDC). Guidelines for the Investigation of Contacts of Persons with Infectious Tuberculosis. MMWR 2005; 54 ( $\left.\mathrm{N}^{\mathrm{o}} \mathrm{RR}-15\right)$ : 1-56.

6. Sociedade Brasileira de Pneumologia e Tisiologia. III Diretrizes para Tuberculose. J Bras Pneumol 2009; 35:1018-1048.

7. Valença MS, Rocha JZ, Ramis IB, Carrion LL, Madruga C, Macedo MB. Improving tuberculosis control through the partnership between university and the health system. Rev Soc Bras Med Trop 2012; 45: 491-495.

8. Pazin-Filho A, Soaresb CS, Ferraisb ASN, Castro PTO, BellissimoRodrigues F, Nogueira JA, et al. Tuberculosis among health care workers in a Brazilian tertiary hospital emergency unit. Am J Emerg Med 2008; 26:796-798.

9. Estevan AO, Oliveira SMVL, Croda J. Active and latent tuberculosis in prisoners in the Central-West Region of Brazil. Rev Soc Bras Med Trop 2013; 46: 515-518.

10. Dagnew AF, Hussein J, Abebe M, Zewdie M, Mihret A, Bedru A, et al. Diagnosis of latent tuberculosis infection in healthy young adults in a country with high tuberculosis burden and BCG vaccination at birth. BMC Research Notes 2012, 5:415-422.

11. Norton BL, Holland DP. Current management options for latent tuberculosis: a review. Inf Drug Resist 2012, 5:163-173. 